\title{
THE UPPER PLEISTOCENE DEGLACIATION ON THE APENNINES (PENINSULAR ITALY)
}

\section{GIRAUDI}

ENEA, C.R. Saluggia, Strada per Crescentino, 41 - 13040 Saluggia, Italy.

\begin{abstract}
The synthesis of the published data and new researches allow to establish a more reliable chronology of the phases of deglaciation that occurred after the Apennine last glacial maximum. The chronological framework was assured by radiocarbon dating and by the presence of four geochemically and chronologically characterized tephra layers and a quartz-rich loess, that were found on different mountain massifs, mainly in Central Italy. After the Campo Imperatore Stade (local LGM) dated 28-27 ka cal BP, a first retreat took place during the Campo Felice Arid Spell, followed by a glaciers advance (Le Capannelle Stade) that started between 26 and $25 \mathrm{ka}$ cal BP. During the readvance the glaciers reached a length about $90 \%$ of the local LGM glacier. The readvance was followed by a retreat broken by at least two readvances (Piano Pietranzoni and Lago Pietranzoni readvances) and then by a very fast withdrawal at the beginning of the Fornaca Interstade, dated ca. 22-21 ka cal BP. The Fontari Stade glacier's advance began ca. $18 \mathrm{ka}$ cal BP and was followed by a retreat broken by at least three small readvances (Fontari 2; Fontari 3; M. Aquila 1). The M. Aquila 1 readvance ended ca. 15-14 ka cal BP. The Venaquaro Interstade, dated 14-13 ka cal BP, was followed by the M. Aquila Stade. This stade was the last Late Pleistocene small glacial expansion and can be correlated to the Younger Dryas. The variations in the atmospheric circulation in the Mediterranean area likely played a role during the first deglaciation phases (between 27-26 and 21-22 ka cal BP). During the period between 19-18 and $12 \mathrm{ka}$ cal BP the glacial fluctuations were linked, very likely, to the climatic impact of the North Atlantic ice rafted debris events. It is possible, therefore, that during the Fornaca Interstade (between 22-21 and 19-18 ka cal $B P)$, there has been such a change in atmospheric circulation and the Central Mediterranean area became more prone to be influenced by the effects of the North Atlantic D/O and IRD events.
\end{abstract}

\section{La deglaciación del Pleistoceno Superior en los Apeninos (Península Italiana)}

RESUMEN. La síntesis de los datos publicados y nuevas investigaciones permiten establecer una cronología más fiable de las fases de deglaciación que ocurrieron después del último máximo glaciar en los Apeninos. El marco crono- 
lógico fue asegurado mediante datación por radiocarbono y por la presencia de cuatro niveles de cenizas volcánicas geoquímica y cronológicamente caracterizados, y un loess rico en cuarzo, que fueron hallados en diferentes macizos de montaña, principalmente en el centro de Italia. Después del Estadio de Campo Imperatore (LGM local), datado en 28-27 ka cal BP, tuvo lugar un primer retroceso durante la Fase Árida de Campo Felice, seguida por un avance de los glaciares (Estadio de La Capannelle) que comenzó entre 26 y $25 \mathrm{ka}$ cal BP. Durante este reavance, los glaciares alcanzaron una longitud del $90 \%$ de la LGM local. El reavance fue seguido por un retroceso interrumpido por al menos dos reavances (de Piano Pietranzoni y Lago Pietranzoni) y luego por un rápido retroceso a comienzos del Interestadio de Fornaca, datado hacia 22-21 ka cal BP. El avance glaciar del Estadio de Fontari comenzó hacia $18 \mathrm{ka}$ cal BP y fue seguido por un retroceso interrumpido por al menos tres pequeños reavances (Fontari 2, Fontari 3 y M. Aquila 1). El reavance de M. Aquila 1 finalizó hacia 15-14 ka cal BP. The Interstadio de Venaquaro, datado en 14-13 ka cal BP, fue seguido por el Estadio de M. Aquila. Este estadio fue la última pequeña expansión glaciar de finales del Pleistoceno y puede correlacionarse con el Younger Dryas. Las variaciones en la circulación atmosférica en el área mediterránea jugaron probablemente un papel importante durante las primeras fases dela deglaciación (entre 27-26 y 21-22 ka cal BP). Durante el periodo entre 19-18 y $12 \mathrm{ka} \mathrm{cal} \mathrm{BP,}$ las fluctuaciones glaciares estuvieron relacionadas, muy probablemente, con el impacto climático de los eventos de hielos flotantes del Atlántico Norte. Es posible, por ello, que durante el Interestadio de Fornaca (entre 22-21 y 19-18 ka cal BP) se haya dado un cambio en la circulación atmosférica, y que el área central del Mediterráneo haya sido más propensa a ser influida por los efectos de la Oscilación del Atlántico Norte y los eventos IRD.

Key words: peninsular Italy, Apennines, late Upper Pleistocene deglaciation, glacial phases, tephra layers, proglacial lacustrine sediments.

Palabras clave: Italia peninsular, Apeninos, final de la deglaciación del Pleistoceno Superior, fases glaciares, niveles de cenizas volcánicas, sedimentos glaciares proglaciares.

Received 17 December 2014 Accepted 30 January 2015

*Corresponding author: ENEA, C.R. Saluggia, Strada per Crescentino, 41 - 13040 Saluggia, Italy. carlo.giraudi@enea.it

\section{Introduction}

The Apennines range, stretching between about $38^{\circ} \mathrm{N}$ and $44^{\circ} 30^{\prime} \mathrm{N}$, retains many traces of the Pleistocene glaciers and particularly those dating back to the local Last Glacial Maximum (LGM) and the following glacial fluctuations (Fig. 1-4; Fig. 5). 


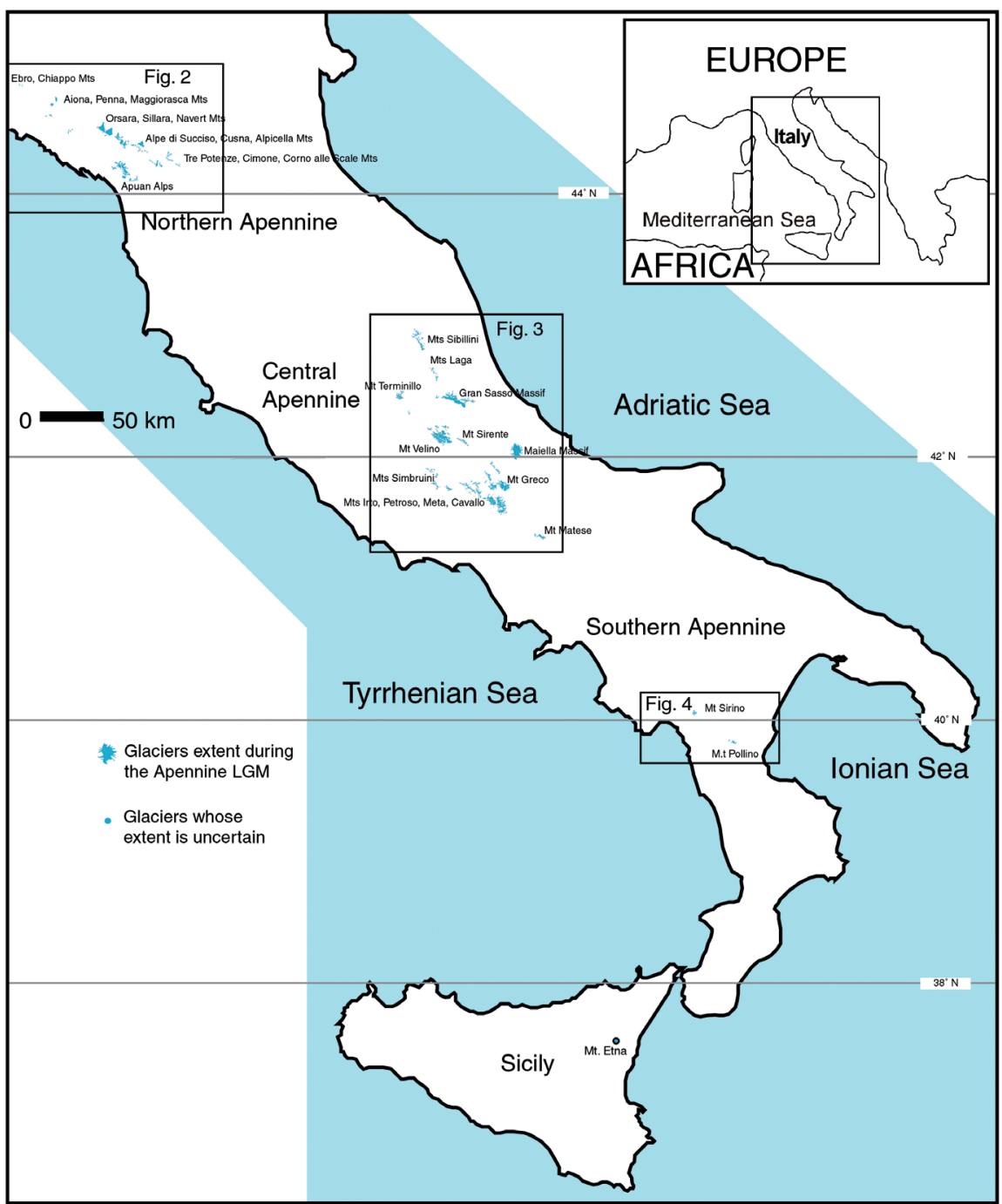

Figure 1. The glaciers in the Apennines during the Campo Imperatore Stade (local LGM). During the following Le Capannelle Stade the extent of the glaciers was only $10 \%$ lower. Adapted from Giraudi (2011).

The difference in latitude, the altitude of the mountains and the orientation of the slopes, have affected, together with the climatic factors, the extent, the Equilibrium Line Altitude (ELA) and the duration of the glaciers.

As known from previous studies, summarized in Giraudi (2011), the ELA during the local LGM and subsequent recessional stades was very variable but generally increased from north to south and from west to east. 


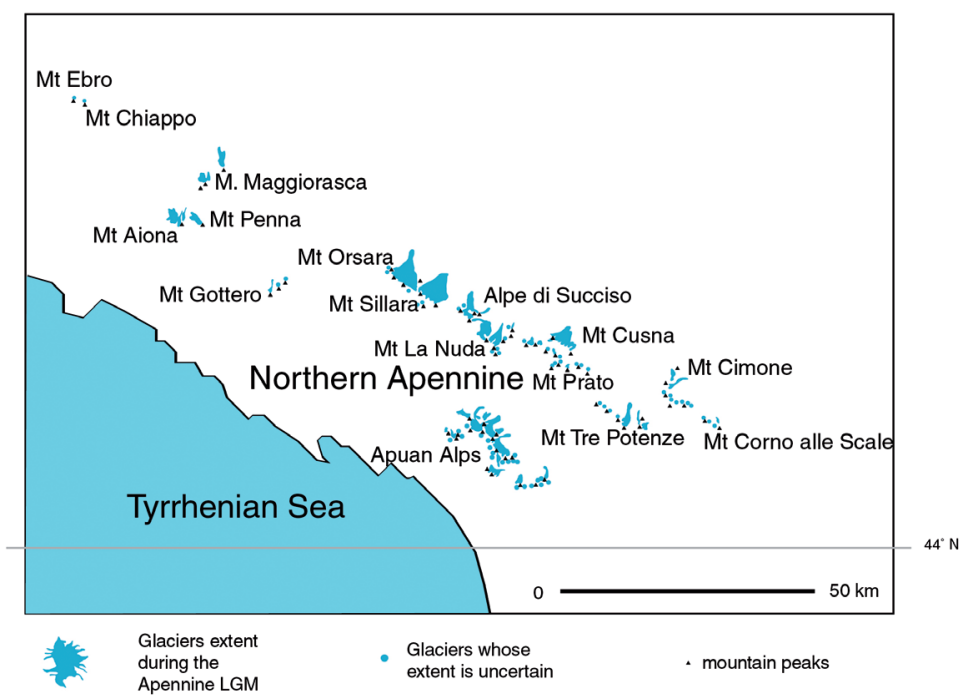

Figure 2. The northern Apennine glaciers during the Campo Imperatore Stade.

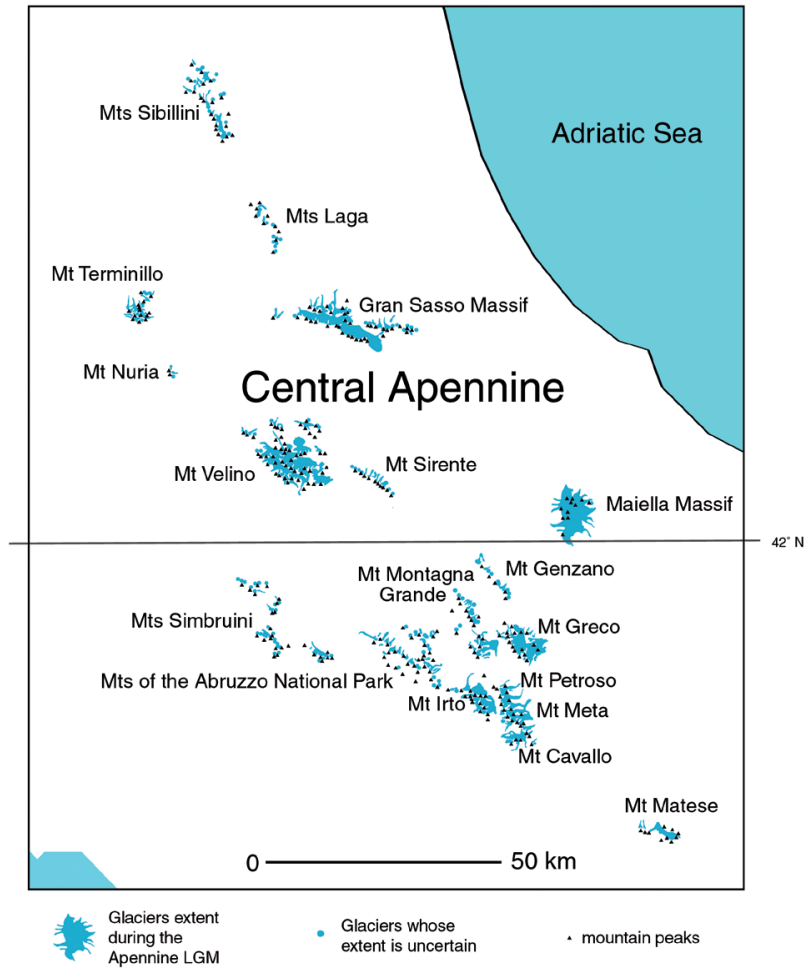

Figure 3. The central Apennine glaciers during the Campo Imperatore Stade. 


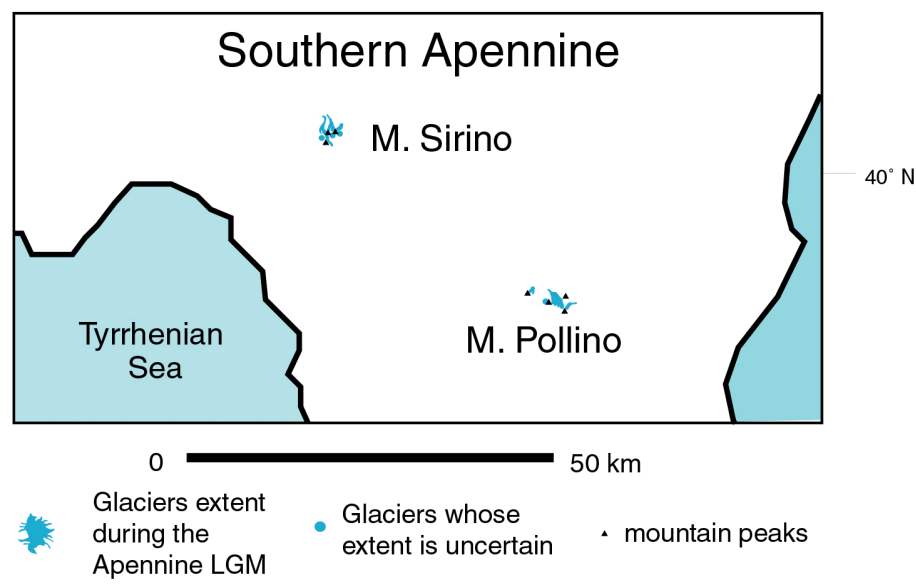

Figure 4. The southern Apennine glaciers during the Campo Imperatore Stade.

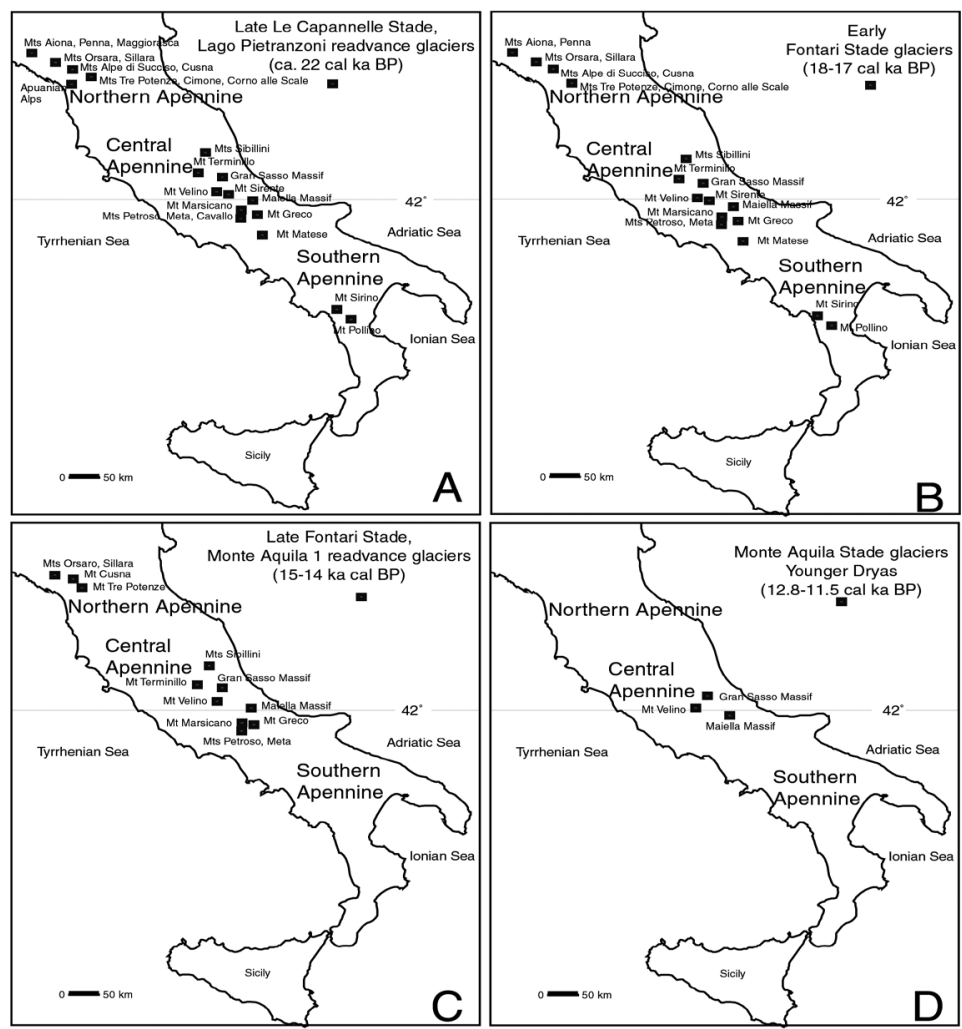

Figure 5. The Apennine mountains with (A) glaciers during the Lago Pietranzoni readvance

(ca. $22 \mathrm{ka}$ cal BP), (B) the early Fontari Stade (18-17 ka cal BP), (C) the Monte Aquila 1 readvance (15-14 ka cal BP) and (D) the M. Aquila Stade (Younger Dryas, 12.8-11.5 ka cal BP). 
The data that may contribute to the chronology of the glacial oscillations, however, are based mainly on two massifs in central Italy: the Gran Sasso (2912 m, the highest mountain in the Apennines) and Mount Velino (2486 m).

Radiocarbon dating of the sediments of a small proglacial lake dammed by the glacial tongue of the local LGM and some soils covered by glaciofluvial sediments, in the first massif (Giraudi and Frezzotti, 1997; Giraudi, 2004a, 2011), and of the deposits of a small proglacial lake that contain interfingered glaciofluvial sediments, in the second one (Giraudi, 2012a), have enabled us to establish a clear chronological correlation between the events recorded in the two massifs.

The datings indicate that the LGM in the Apennines was reached around 28-27 ka cal BP, and that deglaciation was completed at the end of the Younger Dryas or perhaps during the early Holocene.

In the Early Holocene the glaciers disappeared and subsequently only about 4 ka cal BP the Calderone Glacier, still present but extremely reduced, formed again on Mount Corno Grande in the Gran Sasso Massif (Giraudi, 2005).

Studies on glacial fluctuations that occurred after the Apennine LGM started nearly 40 years ago. Beginning from the 70's of the twentieth century, the stades of the deglaciation, witnessed by the remains of lateral and frontal moraine, were tentatively correlated, through the value of the increase in the ELA, with the Alpine stades (Federici, 1979; Palmentola et al., 1990).

Later, the chronology was also based on indirect dating inferred from pollen sequences (Lowe, 1992; Jaurand, 1998), but always assuming that the age of the Apennines LGM matched the global LGM.

Only with the use of radiocarbon dating on proglacial lake deposits, on tephra layers and aeolian sediments younger than the moraines (Giraudi and Frezzotti, 1997; Giraudi, 2004a; 2011), and through the chronology of fluvio-glacial deposits (Giraudi, 2012a) has it been possible to date the local LGM and determine that the stades of deglaciation do not fully correlate with the global LGM and those known in the Alps.

New data on stratigraphic markers and correlations between massifs have helped to improve the glacial chronology for the Apennines.

\section{Methods}

The present study is based on the review of bibliographic data and on the integration between these and the new stratigraphic and chronological data of deposits lying on moraines or in closed depressions located at the back of the moraine ridges.

The stratigraphic data reported in bibliography were obtained observing natural exposures, located within the areas occupied by glaciers during the Upper Pleistocene, digging small trenches, and taking many cores with a hand auger. The highest slopes of the Apennine massifs, in fact, cannot be reached with motor vehicles and, in general, are protected areas or natural parks. 
Several datings were carried out with the radiocarbon method on sediments of small proglacial lakes fed by glacial meltwater, peat and soils. However it should be noted that the dates of the deglaciation are subject to uncertainty in relation to the radiocarbon method and that the dated samples do not always coincide exactly with the boundaries between Apennines glacial stades and interstades.

In order to date and correlate the phases of glacier fluctuations, stratigraphic markers, as tephra layers and quartz-rich loess, have also been used in addition to the radiocarbon datings.

The datings and the stratigraphic markers refer only to some massifs. It follows that the correlation with the glacial fluctuations recorded in the other mountains are mainly based on the relative ELA variations with respect to the ELA during the local LGM. The altitude of the moraines formed during the deglaciation and the stratigraphic data available indicate that in the Apennines the difference between the ELA of the various retreat phases and that of the local LGM (delta-ELA) has been fairly constant (Federici, 1979; Jaurand, 1998; Giraudi, 2004a, 2011). It follows that a date for a moraine formed by a glacier with delta-ELA, for example, of $200 \mathrm{~m}$, can also be used for a moraine with equal delta-ELA present in other Apennine mountains.

\section{Stratigraphic markers used for the chronological framework of the glacial fluctuations}

The sedimentary cover of the LGM and stadial moraines, studied in the higher Apennine massifs on exposures or small cores sampled with hand augers, often consists of the same deposits, that is loess, tephra layers and soils. On the older moraines a more complete sedimentary cover can be found. Among the sediments covering the moraines, some stratigraphic markers have been identified in the various massifs of the southern and central Apennines (Giraudi and Frezzotti, 1997; Giraudi, 2004a; 2011). In order to obtain a reliable chronological framework of the deglaciation, the stratigraphic markers have been characterized and dated. The integration between the chronology suggested by the presence of stratigraphic markers and the dating on lacustrine deposits interbedded with glaciofluvial sediments has enabled a more detailed chronology of the retreat phases to be obtained.

In the present section the markers are evidenced and their age is discussed.

Three of the stratigraphic markers are the same as used by previous Authors (Giraudi and Frezzotti, 1997; Giraudi, 2004a, 2011), i.e. a tephra of the eruption of Mount Etna (Biancavilla-Montalto about 17-18 ka cal BP), the tephra of the Neapolitan Yellow Tuff (NYT-around 13.5-15 ka cal BP), and a quartz-rich loess, but their age range has been modified according to new data.

In the present paper, two more tephra layers that cover moraine deposits have been taken into account. According to Giraudi et al. (2013), they are older than the NYT and, based on geochemical analysis, are related to the two eruptions of the Tufi Biancastri from the Campi Flegrei volcano. 
Even the dating based on tephra layers that are widespread in the Mediterranean area are subject to a variable degree of uncertainty and their exact age is still under discussion.

The tephra layers that are used in order to date the glacial retreat phases are the following.

- The Biancavilla-Montalto tephra, Etna. The older tephra layer lying on some moraines (see below) was produced by an eruption of Mount Etna. It was geochemically characterized by Narcisi (personal communication, 2004), and ascribed to the Biancavilla-Montalto eruption (18-17 ka cal BP). Giraudi (2004a) used the age of the tephra for the chronology of the deglaciation. Later investigations conducted on the volcano, in particular by Albert et al. (2013), have shown that in about $2 \mathrm{ka}$ (about 19-17 ka cal BP) some eruptions occurred on Mount Etna and the lava thereof had a similar chemical composition. It follows that, lacking more detailed geochemical data on the tephra layer found on the moraine, we have to assume that its age is between 19 and $17 \mathrm{ka}$ cal BP.

The same tephra layers, however, are also present in marine and lake cores, interbedded with sediments containing fauna and pollen (Siani et al., 2004; Wulf et al., 2004; Aufgebauer et al., 2012): it is thus possible to know the climate at the time of their sedimentation. The eruptions of Mt. Etna dated between 19 and $17 \mathrm{ka}$ cal BP occurred, according to Albert et al. (2013), during the last glacial-interglacial transition (Termination 1).

- The first Tufi Biancastri tephra. A thin layer of this tephra was found on some moraines of the retreat phases (see below) and described and analyzed in Giraudi et al. (2013). The Tufi Biancastri tephra sedimented, according to Aufgebauer et al. (2012), at the transition between the Oldest Dryas stade and the Bølling / Allerød interstade, therefore ca 16-15 ka cal BP.

- The second Tufi Biancastri Tephra. This was found on some Late Glacial moraines (see below) and its chemical composition and characteristics have been reported in Giraudi et al. (2013). According to Aufgebauer et al. (2012), the second Tufi Biancastri Tephra sedimented probably just after the start of the Bølling / Allerød interstade, i.e. ca 15-14 ka cal BP.

- The Neapolitan Yellow Tuff. The tephra was first found on the glacial deposits (see below) and was already recognized by Frezzotti and Narcisi (1996). It was used for dating glacial phases starting from Giraudi and Frezzotti (1997). According to Siani et al. (2004), Schmidt et al. (2002), Wulf et al. (2004), the tephra sedimented during the Bølling / Allerød interstade and is stratigraphically within the Greenland Interstadial I (GI-1) in the Greenland event stratigraphy, that is ca $14-13 \mathrm{ka}$ cal BP.

In addition to the tephra layers, also a loess has been used as a stratigraphic marker. The results of new studies suggest that it is a quartz-rich loess, Saharan in origin (Giraudi et al., 2013). Interbedded in the upper part of the loess is the tephra layer of the first Tufi 
Biancastri eruption, while the tephra of the second eruption covers the loess. On the basis of the stratigraphic framework, the age of the tephra layers and of a peat layer lying at the top, dated $15.7 \pm 0.8 \mathrm{ka}$ cal BP, and the chronological correlation with the Saharan climatic events, the end of the sedimentation of the loess was estimated at around $15 \mathrm{ka}$ cal BP and may coincide with the start of the Bølling / Allerød Interstade.

\section{The Apennines deglaciation}

The chronology of the glacial fluctuations that will be discussed below was established originally for the Gran Sasso massif (Fig. 6) by Giraudi and Frezzotti (1997). New data were taken into consideration in Giraudi (2004a), and later modified according to the chronology arising from the studies of Campo Felice (Velino massif) reported in Giraudi (2012a). The dating of the moraines has been based on the presence, in closed depressions lying on the local LGM and on later till, of the stratigraphic markers described above, but also on volcanic-rich aeolian sediments derived from tephra layers, soils and colluvia. The loess is the first deposit that can be found on the moraines of the local LGM.

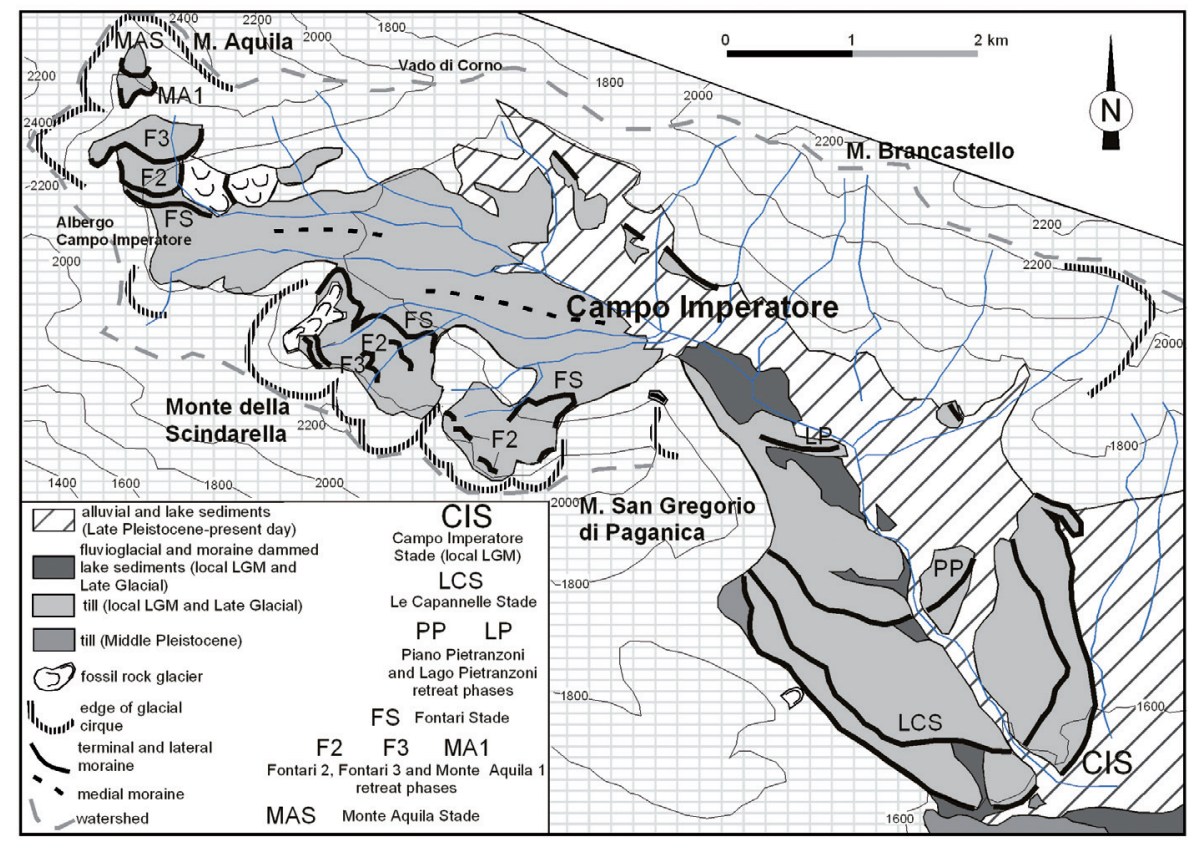

Figure 6. The glacial heritage at Campo Imperatore (Gran Sasso Massif). In the map are evidenced the frontal and lateral moraines that have been used to define the Apennine glacial stades.

According to the last synthesis of the Apennines glacial fluctuations (Giraudi, 2012a) the Apennines LGM is named Campo Imperatore Stade. The start of the deglaciation matches the ice recessional event that occurred during the Campo Felice Arid Spell. A glacial expansion (Le Capannelle Stade) followed and then the Fornaca Interstade 
glacial retreat. A new glacial expansion (Fontari Stade) was followed by the Venacquaro Interstade. The last Late Pleistocene, very small, glacial expansion is the Monte Aquila Stade. After the Monte Aquila Stade the glaciers melted and only during the second half of the Holocene did a new glacier form (Calderone Stade - Giraudi, 2005, 2011) on the Corno Grande (Gran Sasso Massif), the highest peak of the Apennines.

The Corno Grande where, due to its altitude, any Holocene glacial fluctuations older than the climatic optimum could have been recorded, has very steep slopes towards the northern quadrants. The morphology of the slopes does not allow the preservation of any glacial deposits that may indicate the deglaciation of this massif occurred between the Younger Dryas and 4000 cal yr BP.

Below are reported, in summary, the data needed to characterize the timing of the deglaciation starting from Campo Imperatore Stade. Apennine stadial phases and their duration are shown in Figure 7.

All the data and the interpretations reported in the present chapter are from published papers and have been discussed in Giraudi and Frezzotti (1997), Giraudi (2004a, 2011, 2012a) and Giraudi et al. $(2011,2013)$. The summary of the data and the interpretation of the climate during the deglaciation made it possible to improve the chronology and the correlations with climatic changes recorded in peninsular Italy by sediments and pollen, and with North Atlantic climatic events.

\section{Campo Imperatore Stade = Apennine LGM}

The most precise dating of the maximum glacial expansion has been obtained on the Gran Sasso Massif (Giraudi and Frezzotti, 1997), where the glacial tongue of the Campo Imperatore Stade has dammed a small tributary valley thus helping to create a small proglacial lake, mainly fed by glacial meltwater. The lacustrine sediments have been dated back to ca 28-27 ka cal BP (Fig. 7). The date closest to the maximum expansion is $27.13 \pm 0.84 \mathrm{ka}$ cal BP.

The oscillations of Lake Campo Felice and the interfingering between glaciofluvial and lacustrine sediments have enabled us to establish that during the Campo Imperatore Stade the lake level was very high (Giraudi, 2012a).

During the Apennines LGM, the ELA was between 1250 and $1550 \mathrm{~m}$ in the northern Apennines, between 1550 and $1900 \mathrm{~m}$ in the central Apennines, and between 1600 and $1800 \mathrm{~m}$ in the southern Apennines.

Figure 1 shows the size of the Campo Imperatore Stade glaciers. According to Giraudi and Frezzotti (1997) during the local LGM, the mean annual temperature was $\sim 7.3-8.3^{\circ} \mathrm{C}$ lower than the present, based on the altitude of fossil rock glaciers. During the same period, the amount of the snowfall was nearly equal to that at present. The precipitation has been valued using a formula that considers the differences in temperature with the present and the results of Ohmura et al. (1992), according to which the effect on a glacier of a temperature variation of $1^{\circ} \mathrm{C}$ is similar to that produced by a change in yearly snowfall of about 300-400 $\mathrm{mm}$ water equivalent. 
The mineralogical composition of the proglacial lake sediments formed during the Apennine LGM, studied on the Gran Sasso Massif and on Mount Terminillo (Giraudi et al., 2013), shows a quartz percentage of around 20\%. Because the areas which were covered by ice during the Campo Imperatore Stade are formed by carbonate rocks, it has been hypothesized that the quartz derives from aeolian sedimentation. In the same period, quartz-rich Saharan dust sedimented in the Vico lake (Narcisi, 2001) and on high mountains of the central and southern Apennines (Giraudi et al., 2013), but also on the Mediterranean island of Lampedusa (Giraudi, 2004b).

\section{Campo Felice Arid Spell}

The oscillations of Lake Campo Felice and the interfingering between glaciofluvial and lacustrine sediments have made it possible to establish that the Campo Imperatore Stade was followed by a retreat phase during which the lake level was very low. The retreat phase, called Campo Felice Arid Spell (Giraudi, 2012a) can be dated at the period between 26 and $25 \mathrm{ka}$ cal BP (Fig. 7). Thus, the beginning of the deglaciation in the Apennines is related to the aridity of the climate, as suggested also by Giraudi and Frezzotti (1997).

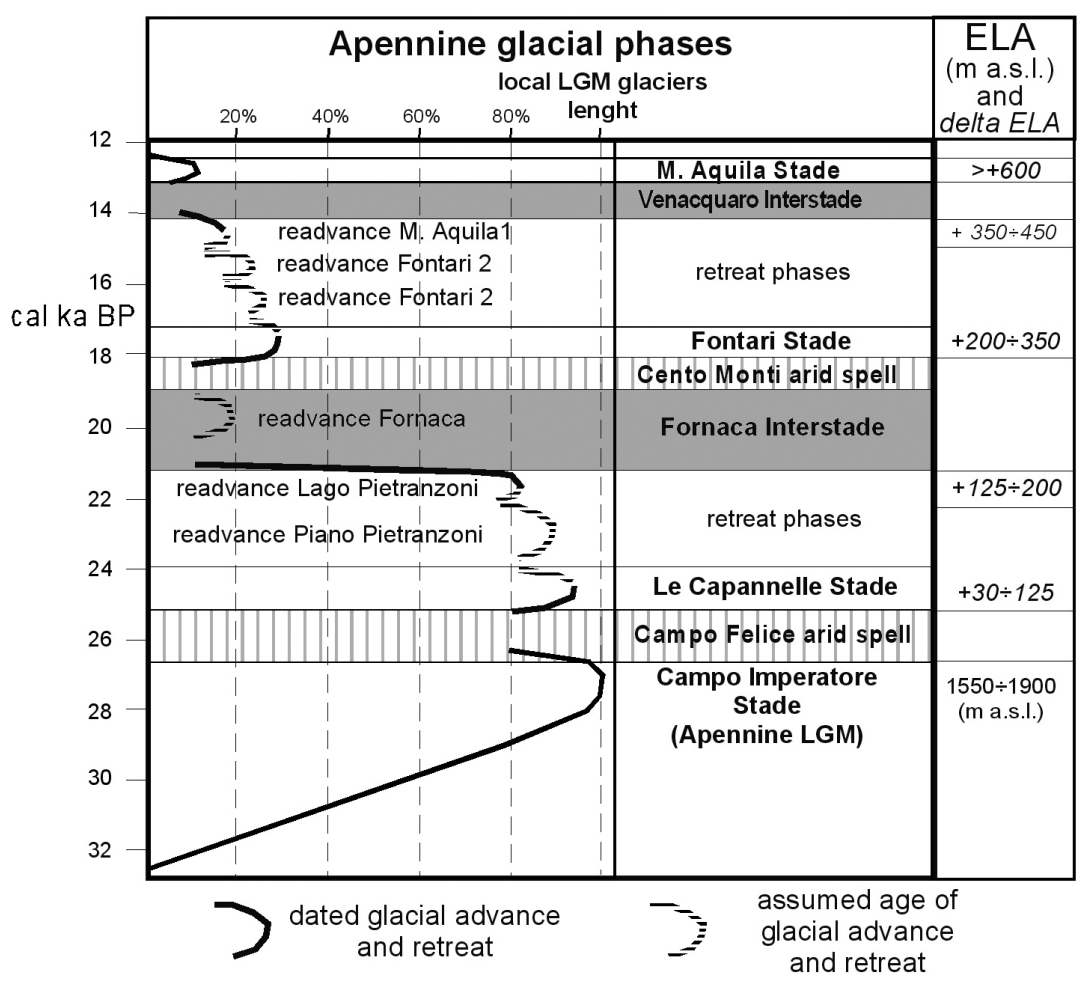

Figure 7. Chronology of the Apennine LGM and the deglaciation according to Giraudi (2012a). 


\section{Le Capannelle Stade}

After the Campo Felice Arid Spell, there was a glacial readvance (Le Capannelle Stade) that led the glaciers to reach a length equal to $90 \%$ of that achieved during the maximum expansion (Fig. 7).

All the glaciers of the central and southern Apennines were affected by this readvance, and the distribution of Le Capannelle Stade glaciers corresponds to that of the Campo Imperatore Stade (Fig. 1-4). The data of the northern Apennines are discontinuous because the glacial deposits are less preserved. For the central Apennines the difference (delta ELA) between the ELA of the Campo Imperatore Stade and ELA of the Le Capannelle Stade is variable, but on the massifs where this glacial readvance is better dated, the delta ELA is estimated at around +30 to $+50 \mathrm{~m}$.

Based on the ages of the lacustrine deposits of Campo Felice and of the Campo Imperatore soils (Giraudi, 2012a; Giraudi and Frezzotti, 1997) the Le Capannelle Stade (Fig. 7) began around 26-25 ka BP (the closest radiocarbon date is $25.62 \pm 0.45 \mathrm{ka}$ cal BP) and the glacier reached its maximum length of the stade between 25 and $24 \mathrm{ka} \mathrm{cal}$ BP. On the Gran Sasso and Mount Velino, the end of the Le Capannelle Stade is dated between approximately 22 and $21 \mathrm{ka}$ cal BP (the closest radiocarbon date is $21.4 \pm 0.45 \mathrm{ka}$ cal BP). During the retreat phase (between 24 and 22-21 ka cal BP) the glaciers readvaced at least twice more (Piano Pietranzoni and Lago Pietranzoni readvances). During the two episodes of readvance the glaciers still reached about 85 and $80 \%$ of the extension of the Campo Imperatore Stade glaciers and the delta ELA between the glaciers of the Lago Pietranzoni and the maximum expansion is always less than $+200 \mathrm{~m}$. During the Lago Pietranzoni readvance the average annual temperature calculated by Giraudi and Frezzotti (1997) was about 5.7-6.7 ${ }^{\circ} \mathrm{C}$ lower than at present and the snowfall less than or equal to the current values. The quartz-rich loess is the first sediment overlying the glacial deposits of Le Capannelle Stade and of its retreat phases.

\section{Fornaca Interstade}

A very strong glacial recession, known as the Fornaca Interstade, took place after the Lago Pietranzoni readvance (Giraudi and Frezzotti, 1997). Based on the dates obtained on the Gran Sasso and Mount Velino, the Fornaca Interstade started between 22 and $21 \mathrm{ka} \mathrm{cal} \mathrm{BP} \mathrm{(Fig.} \mathrm{7).} \mathrm{The} \mathrm{length} \mathrm{of} \mathrm{the} \mathrm{glacier} \mathrm{was} \mathrm{less} \mathrm{than} 30 \%$ of that reached during the Campo Imperatore Stade. According to the Campo Felice data it is possible that during the Fornaca Interstade a small glacial readvance (Fornaca readvance) took place. The final phase of the Fornaca Interstade is a very arid period called the Cento Monti Arid Spell by Giraudi (2012a).

\section{Fontari Stade}

The glacial advance named the Fontari Stade followed the Fornaca Interstade (Giraudi and Frezzotti, 1997). During this stade the glaciers reached a length equal to $30 \%$ of that achieved during the local LGM. The delta-ELA between the ELA-Campo 
Imperatore Stade and ELA-Fontari Stade on the Central Apennine massifs, where the glacial deposits are better preserved, is equal to or higher than $+250 \mathrm{~m}$, but also in the northern and southern Apennines the values are similar (Giraudi, 2011). Although during the Fontari Stade the glaciers were still widespread, in the lower mountains they began to disappear (Fig. 5A).

Based on the age of the lacustrine sediments of Campo Felice, which contain interbedded glaciofluvial sandy gravel, and soils which, at Campo Imperatore (Gran Sasso Massif), lie on glaciofluvial sediments, the Fontari Stade began between 19 and 18 $\mathrm{ka}$ cal BP (the closest radiocarbon date is $18.42 \pm 0.27 \mathrm{ka}$ cal BP) and around $18 \mathrm{ka}$ cal BP the glaciers would have reached the maximum size of this period (Fig. 7). Later, during the following glacial recession at least three readvances took place (Fontari 2; Fontari 3; M. Aquila 1) and the length of the glaciers correspond respectively to nearly 25,22 , and $18 \%$ of the Campo Imperatore Stade one.

According to Giraudi and Frezzotti (1997) at the beginning of the Fontari Stade the average yearly temperature was ca. $6^{\circ} \mathrm{C}$ lower than the present time and the amount of the snowfall was similar. The delta-ELA during the M. Aquila 1 readvance reached ca. $+450 \mathrm{~m}$. The increase in the ELA altitude caused the melting of many glaciers including all those in the southern Apennine (Fig. 5C). According to Giraudi and Frezzotti (1997) during the Fontari Stade the average yearly temperature was ca. $5.4^{\circ} \mathrm{C}$ lower than at present, while the amount of the snowfall was less.

The datings of the glacier readvances and recessions occurred during the Fontari Stade are also based on the age of several markers. The first sediment lying on the oldest moraines pertaining to the Fontari Stade is the quartz-rich loess, but on the Velino Massif the tephra from Mt. Etna was found. Therefore the Fontari Stade retreat phases started before the fall of the tephra (Fig. 8). As noted earlier, it is not possible to determine which of the eruptions dated between 19 and $17 \mathrm{ka}$ cal BP produced said tephra layer. However, since the glacial expansion began between 19 and $18 \mathrm{ka}$ cal BP and the maximum glacial expansion of the Fontari Stade was reached around $18 \mathrm{ka}$ cal BP, it is unlikely that the tephra is correlated to the eruption dated around $19 \mathrm{ka}$ cal BP.

The oldest sediment lying on the readvance Fontari 2 moraine on the Mount Matese is the quartz-rich loess having an interbedded tephra layer. According to Giraudi et al. (2013) the tephra layer's geochemical composition suggest that it was formed during the older Tufi Biancastri eruption.

As explained above, the fall of the tephra seems to have occurred just before the transition between Oldest Dryas and the Bölling / Allerod, i.e. shortly before $15 \mathrm{ka}$ cal BP.

The glacial readvance Fontari 2 should therefore be contemporary to or, more likely, younger than the fall of the tephra of Mount Etna and older than the fall of the first Tufi Biancastri tephra. It follows that its age is between 17 and $15 \mathrm{ka} \mathrm{cal} \mathrm{BP} \mathrm{(Fig.} \mathrm{8).}$ 
The moraines of the Fontari 3 readvance are the first ones lacking a quartz-rich loess cover (Fig. 8), and the bottom of the sediments lying on them is formed by the second Tufi Biancastri tephra layer.

The glacial readvance was, therefore, simultaneous with, or subsequent to, the sedimentation of the loess and the fall of the first Tufi Biancastri tephra. The Fontari 3 readvance is older than the start of the Bölling/Alleröd Interstade and should be dated at the period between 16 and $15 \mathrm{ka}$ cal BP.

During these three readvaces, glaciers could have been present only on the highest mountains of the central and northern Apennines (Fig. 5C).

About the Mount Aquila 1 readvance, it should be noted that the first sediments that lie on glacial deposits are represented by the tephra from the NYT or by the products of its aeolian and colluvial reworking (Fig. 8). The M. Aquila 1 readvance, recorded only on the highest northern and central Apennine Mountains (Fig. 5C), occurred after a retreat that followed the Fontari 3 readvance and before the fall of the NYT tephra. Therefore it should be dated at the first period of the Bölling/Alleröd Interstade, that is between ca. 15 and 14 ka cal BP (Fig. 8).

\section{Venaquaro Interstade}

The occurrence of this interstade is demonstrated by the presence, in a glacial cirque on the Gran Sasso massif, of lacustrine sediments dated around 14-13 ka cal BP (Giraudi and Frezzotti, 1997). These sediments were deposited during a period of high summer temperatures during which strong evaporation occurred also at an altitude close to $2000 \mathrm{~m}$. During the Venacquaro Interstade, all the glaciers of the northern Apennines and almost all the other remaining glaciers melted.

\section{Aquila Stade}

During the M. Aquila Stade, a few small glaciers formed only on the highest massifs of the central Apennines, i.e. on Gran Sasso, Majella and Velino (Fig. 5D). The delta-ELA between the ELA-Campo Imperatore Stade and ELA-M. Aquila Stade is $+550 / 600 \mathrm{~m}$. The maximum length reached by the glaciers was nearly $10 \%$ of that of the local LGM glaciers.

According to Giraudi and Frezzotti (1997), during the M. Aquila Stade the mean annual temperature was between 5.6 and $6.7^{\circ} \mathrm{C}$ lower than at present and the amount of snowfall was lower by a value of between $300-400$ and $600-800 \mathrm{~mm} /$ year.

The M. Aquila Stade is older than $8.8 \pm 0.4$ ka cal BP (Giraudi and Frezzotti, 1997). The age of the melting of the glaciers is unknown. The sediments that lie on the moraines are colluvia of local origin: the disappearance of the glaciers therefore occurred after the fall of the NYT (Fig. 8).

According to the chronological and climatic framework, Giraudi and Frezzotti (1997), Giraudi (2004a, 2011), assumed that the M. Aquila Stade corresponds to the 
Younger Dryas, because during the period between 13 and 8.8 $\pm 0.4 \mathrm{ka}$ cal BP no other cold spell reaching such a low mean yearly temperature was recorded.

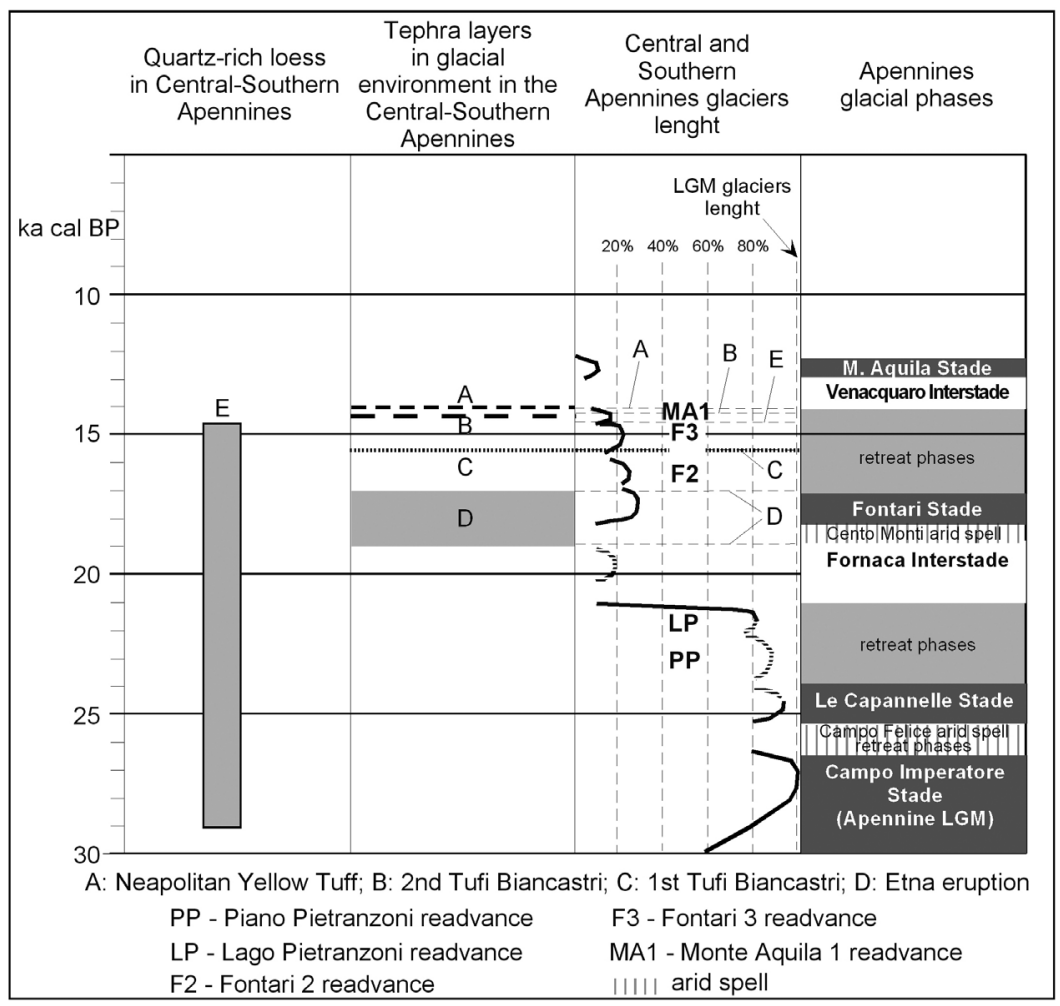

Figure 8. Chronological framework of the stratigraphic markers and the new chronology of the glacial fluctuations.

\section{Discussion}

The data reported above show that the deglaciation on the Apennines started between 26 and $25 \mathrm{ka}$ cal BP, the Campo Imperatore Stade being dated between 28 and 27 ka cal BP.

The deglaciation in the Apennines appear to have been punctuated by abrupt events, probably lasting less that a thousands years, that do not depend directly on the orbital variations of the Earth (lasting thousands of years) which caused the Ice Ages. Abrupt events have different characteristics.

As already suggested by Giraudi and Frezzotti (1997), the beginning of the deglaciation is linked to a climate change (Campo Felice Arid Spell) that marked the 
transition from a cold wet period (Campo Imperatore Stade) to a very cold dry one (the Capannelle Stade).

The transition from the Le Capannelle Stade to the Fornaca Interstade seems to correspond to an abrupt temperature increase that produced a dramatic glacier retreat.

The transition between the Fornaca Interstade and the Fontari Stade took place after the Cento Monti Arid Spell, a cold dry event very similar to the previous Campo Felice spell.

The end of the Fontari Stade and the melting of most Apennine glaciers seem to indicate a sudden increase in the temperature.

Finally, the M. Aquila Stade glaciers advance was linked to an abrupt temperature drop.

It is also clear that the different ice recessional events do not correspond to the same climatic conditions.

The Campo Felice Arid Spell was cold and dry, the Fornaca Interstade was mild but, later, during the Cento Monti Arid Spell, the climate was cold and dry, and lastly, in the Venacquaro Interstade, was mild-warm.

The dating of the episodes of glacial advance and retreat occurred in the Apennines enables correlations to be made with other proxy-data relating to continuous sedimentary sequences. In particular it is possible to make correlations with the variations in the characteristics of the sediments and with the pollen associations found in the sediments of lakes Vico, Mezzano, Stracciacappa, Monticchio and Accesa (Fig. 9).

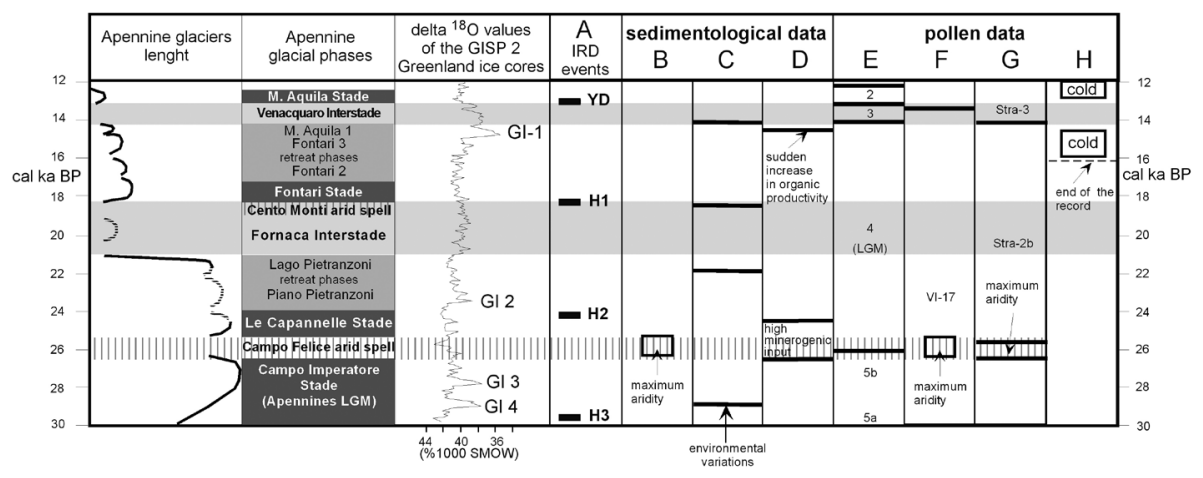

Figure 9. Comparison between the chronological framework of the Apennine glacial fluctuations, the North Atlantic delta ${ }^{18} \mathrm{O}$ values in the GISP ice core, the IRD events, and the age of the environmental variations shown by sedimentology and palynology in sedimentary records of the Italian peninsula. Column A: IRD events from Bond et al. 1997; Columns B, C, $D=$ sedimentary data; B: Lago di Vico from Narcisi (2001); C: Lago Grande di Monticchio,

from Zolitschka and Negendank (1996); D: Lago di Mezzano, from Ramrath et al. (1999);

Columns E,F,G,H: pollen data; E: Lago Grande di Monticchio, from Watts et al. (1996),

Huntley et al. (1999); F: Lago di Vico, from Magri and Sadori (1999); G: former Lago

Stracciacappa, from Giardini (2007); H: Lago dell'Accesa, from Magny et al. (2006). 
The study of the sediments of Lago di Vico carried out by Narcisi (2001), apart from evidencing an increase in the amount of clastic sediments during the cold phases, shows that around $26 \mathrm{ka}$ cal BP (Fig. 9, column B), i.e. during the Campo Felice Arid Spell, the climate was cold and very dry.

Zolitschka and Negendank (1996), who studied the mineralogical characteristics of the sediments in the cores at the Lago Grande di Monticchio, evidence variations in the composition of the sediments (Fig. 9, column C), and therefore environmental variations, that occurred in the following periods: around $29 \mathrm{ka} \mathrm{cal} \mathrm{BP}$, shortly before the maximum expansion of the Campo Imperatore Stade was reached; around $22 \mathrm{ka} \mathrm{cal} \mathrm{BP}$, that is at the start of the rapid glacial retreat which led to the Fornaca Interstade; around $18.5 \mathrm{ka}$ cal BP, the age of the Cento Monti Arid Spell and the start of the Fontari Stade, and shortly before $14 \mathrm{ka}$ cal BP, corresponding to the start of the Venacquaro Interstade.

The study of the sediments of Lake Mezzano (Ramrath et al., 1999) shows, in general, an increased percentage of clastic sediments during the marine isotope stade (MIS) 2. However, the study evidences (Fig. 9 column D) that around 26.5 and $24.5 \mathrm{ka}$ cal BP, i.e. as from the beginning of the Campo Felice Arid Spell and until the Le Capannelle Stade, there was a higher clastic input.

There is thus a good chronological correlation between the sediment variations in the lakes of peninsular Italy and glacial oscillations in the Apennines.

The chronological correlation between the glacial fluctuations and the environmental variations evidenced by the pollen studies has to date been addressed only in part. Nimmergut et al. (1999) observed that at most there can be an overlap of about 500 years between the LGM indicated by the pollen in the sediments of Lago Grande di Monticchio and the LGM of the Apennine glaciers, reported by Giraudi and Frezzotti (1997), the maximum expansion of the Apennine glaciers being older. The chronological correlation was however difficult because, while the pollen data were dated with the varve-chronology, the data on glacial expansion were expressed in ${ }^{14} \mathrm{C}$ yr BP. Hughes et al. (2006), comparing the dates of the LGM of the glaciers in the Apennines, reported in Giraudi and Frezzotti (1997), and of the LGM indicated by the pollen of Lago Grande di Monticchio, state that the two events were not synchronous.

The new definition of the chronological extent of the Apennines stadial and interstadial phases has enabled far more precise chronological correlations to be made with the data reported in pollen studies.

Figure 9 (columns E,F,G,H) shows the considerable chronological correspondence between the environmental variations indicated by pollen and those shown by the glaciers, but it shows that the Campo Imperatore Stade glacial expansion occurred before the coldest and most arid period indicated by the pollen. When, according to the pollen data (Fig. 9, column E), the temperature and the humidity reached their lowest values (Pollen zone 4 at Lago Grande di Monticchio in Nimmergut et al., 1999) the Apennine glaciers had already diminished in size, but were still close to their maximum dimensions. The limit between pollen zone 5 and 4 recorded in the sediments of Lago Grande di Monticchio (Nimmergut et al., 1999) is synchronous with the Campo Felice 
Arid Spell. Moreover the dating of the end of the glacial period in the same lake is synchronous with the start of the Venacquaro Interstade and pollen zone 2 coincides with the M. Aquila Stade.

According to Magri and Sadori (1999) the pollen in the sediments of Lago di Vico (Fig. 9, column F) indicates that the most arid period can be dated at around $26 \mathrm{ka} \mathrm{cal} \mathrm{BP}$ and is therefore contemporaneous with the Campo Felice Arid Spell.

The pollen zones identified by Giardini (2007) in the sediments of the former Lake Stracciacappa (Fig. 9, column G) can be correlated chronologically with various events evidenced in the study of the Apennine glacial traces. The limit between pollen zones Stra-2b and Stra-3, corresponding with the end of the glacial period, can be correlated chronologically with the start of the Vanacquaro Interstade; furthermore the most arid phase at Stracciacappa (almost total disappearance of tree pollen around 26 cal ka BP) coincides chronologically with the Campo Felice Arid Spell.

Magny et al. (2006) who studied the sediments in Lake Accesa (Fig. 9, column $\mathrm{H})$ approximately dated at the last $16 \mathrm{ka}$, identify two periods characterized by low temperatures: the first one, which can be put at around 16-15 cal ka BP, corresponds with the last phases of the Fontari Stade, while the second one, dated around 12-13 cal ka BP, considered coeval with the Younger Dryas, can be correlated chronologically with the M. Aquila Stade.

In conclusion, the most important element evidenced by the chronological correlation between glacial fluctuations and the climatic variations indicated by the pollen is represented by the fact that the Apennine glaciers were already retreating during the coldest period indicated by the pollen. However, the age of the start of the coldest period shown by the pollen studies seems to match the change, recorded by the glacial environment, between cold and wet and very cold and dry periods that led to the first glacial retreats.

The climatic changes that affected the glacial fluctuations, therefore, were recorded at least throughout the Italian peninsula.

Starting from the assumption that, in general, the glacial oscillations lasting many thousands of years are connected to variations in the insolation produced by the orbital position of the Earth, it remains to identify the link between abrupt phases of glacial fluctuations and regional and global climatic events.

Among the possible causes of the glacial changes recorded during deglaciation, there are the $\mathrm{D} / \mathrm{O}$ and ice rafted debris (IRD) events in the North Atlantic.

Some authors (Watts et al., 1996; Brauer et al., 2000) hypothesize correlations between the Upper Pleistocene environmental changes that occurred in the North Atlantic, identified by Bond et al. (1997), Andersen et al. (2006), EPICA (2006), Svensson et al. (2006; 2008), and those recorded in the Italian peninsula. However, according to some authors, even during the last $10 \mathrm{ka}$, there is a correlation between events in the North Atlantic and the Mediterranean (Magny et al., 2006; Sadori et al., 2011; Giraudi, 2012b). 
Figure 9 evidences the possible correlations between glacial oscillations and North Atlantic D/O and IRD events.

The Apennine LGM (Campo Imperatore Stade) corresponds to the period during which, in Greenland, the interstades GI 3 and GI 4 (Svensson et al., 2006, 2008) took place. During the Le Capannelle Stade, in Greenland the climate was very cold but the Interstade GI 2 also occurred.

The climatic framework seems to confirm the Hughes and Woodward (2008) hypothesis which suggests a link between the maximum glacial expansions in the Mediterranean area and periods of non-extreme climate.

- The age of the Greenland Interstade GI 1 matches that of the last retreat phases of the Fontari Stade, that is a period of strong glacial retreat, and of the Venacquaro Interstade.

The correlation between Apennine glacial oscillations and North Atlantic IRD events highlights some elements of interest.

- The North Atlantic H3 event was contemporary with the expansion of the Campo Imperatore Stade glaciers, but the expansion began earlier and continued later. It follows that the $\mathrm{H} 3$ event's influence on the Apennine glaciers may have been only marginal.

- The event H2 took place during the Le Capannelle Stade but, as in the previous case occurred when the glacial expansion had already begun. At best, the $\mathrm{H} 2$ event influenced one of the glacial readvances that occurred during the retreat phases.

- The H1 event however coincides with a strong environmental variation in the Apennines. The date that approximates best the beginning of the Fontari Stade $(18.42 \pm$ $0.27 \mathrm{ka}$ cal BP) is very close to that of the beginning of $\mathrm{H} 1$.

- The Younger Dryas event corresponds to the M. Aquila Stade.

The possible correlation with D/O and IRD events suggests that, probably, for the period between about 30 and $21 \mathrm{ka}$ cal BP there is an inverse correlation between the temperatures of the North Atlantic and the glacial fluctuations in the Apennines but, starting from 19-18 ka cal BP, the correlation becomes direct.

It follows that during the Fornaca Interstade a change must have occurred in the climatic factors that determined the glacial oscillations and that the change must be sought in the Mediterranean area.

It is possible that this change was driven by variations in the atmospheric circulation, in particular of the flow of southern air masses which, according to Florineth and Schlüchter (2000), influenced the expansion of the Alpine glaciers during LGM.

\section{Conclusions}

The synthesis of the stratigraphic data, the dating of the sediments of proglacial lakes and of a loess, and the geochemical characterization of four tephra layers lying 
on glacial deposits, have enabled the chronological framework of the deglaciation to be defined more accurately.

It was thus possible to correlate the glacial phases with events recorded by sediments and pollen studied in cores taken in several lakes of peninsular Italy, but also to hypothesize the correspondence with some North Atlantic D/O and IRD events.

The deglaciation events can be summarized as follows.

After the Campo Imperatore Stade (local LGM) a first retreat took place during the Campo Felice Arid Spell, followed by a glacier advance (Le Capannelle Stade). During the readvance the glaciers reached a length about $90 \%$ of the Campo Imperatore Stade glacier. The readvance was followed by a retreat broken by at least two small readvances (Piano Pietranzoni and Lago Pietranzoni readvances) and then by a very fast withdrawal at the beginning of the Fornaca Interstade.

During the first deglaciation phases (between 26-25 and 22-21 ka cal BP) the glacial oscillations cannot be directly linked with the North Atlantic D/O and IRD events, but the variations in the atmospheric circulation in the Mediterranean area probably played a role.

The Fontari Stade glaciers advance was followed by a slow retreat phase broken by at least three small readvances (Fontari 2; Fontari 3; M. Aquila 1). The Fontari Stade began ca. $18 \mathrm{ka} \mathrm{cal} \mathrm{BP}$ and ended ca. 15-14 ka cal BP.

The last late Upper Pleistocene small glacial expansion occurred during the $\mathbf{M}$. Aquila Stade that can be correlated with the Younger Dryas.

No data allow it to be established whether some small glaciers lasted until the early Holocene.

During the period between 19-18 and $12 \mathrm{ka}$ cal BP the glacial phases were linked, very likely, with North Atlantic events.

It is possible, therefore, that during the Fornaca Interstade (between 22-21 and 19-18 ka cal BP), there was such a change in atmospheric circulation that the Central Mediterranean area became more prone to be influenced by the effects of the North Atlantic D/O and IRD events.

\section{References}

Albert, P.G., Tomlinson, E.L., Lane, C.S., Wulf, S., Smith, V.C., Coltelli, M., Keller, J., Lo Castro, D., Manning, C.J., Müller, W., Menzies, M.A. 2013. Late glacial explosive activity on Mount Etna: Implications for proximal-distal tephra correlation and synchronisation of Mediterranean archives. Journal of Volcanology and Geothermal Research 265, 9-26.

Andersen, K.K., Svensson, A., Johnsen, S.J., Rasmussen, S.O., Bigler, M., Röthlisberger, R., Ruth, U., Siggaard-Andersen, M.L., Steffensen, J.P., Dahl-Jensen, D., Vinther, B.M., Clausen, H.B. 2006. The Greenland ice core chronology 2005, 15-42 ka. Part 1: constructing the time scale. Quaternary Science Reviews 25, 3246-3257. 
Aufgebauer, A., Panagiotopoulos, K., Wagner, B., Schaebitz, F., Viehberg, F.A., Vogel, H., Zanchetta, G., Sulpizio, R., Leng, M.J., Damaschke, M. 2012. Climate and environmental change in the Balkans over the last $17 \mathrm{ka}$ recorded in sediments from Lake Prespa (Albania/ F.Y.R. of Macedonia/Greece). Quaternary International 274, 122-135.

Bond, G., Showers, W., Cheseby, M., Lotti, R., Almasi, B., deMenocal, P., Priore, P., Cullen, H., Hajdas, I., Bonani, G. 1997. A pervasive millennial scale cycle in North Atlantic holocene and glacial climates. Science 278, 1257-1266.

Brauer, A., Mingram, J., Frank, U., Günter, C., Schettler, G., Wulf, S., Zolitschka, B., Negendank, J. 2000. Abrupt environmental oscillations during the Early Weichselian recorded at Lago Grande di Monticchio, southern Italy. Quaternary International 73/74, 79-90.

EPICA Community Members. 2006. One-to-one coupling of glacial climate variability in Greenland and Antarctica. Nature 444, 195-198.

Federici, P. 1979. Una ipotesi di cronologia glaciale würmiana, tardo e post- würmiana nell'Appennino Centrale. Geografia Fisica Dinamica Quaternaria 2, 196-202.

Florineth, D., Schlüchter, C. 2000. Alpine evidence for atmospheric circulation patterns in Europe during the Last Glacial Maximum. Quaternary Research 54, 295-308.

Frezzotti, M., Narcisi, B. 1996. Late Quaternary tephra-derived palaeosols in central Italy's carbonate Apennine range: stratigraphical and palaeoclimatological implications. Quaternary International 34-36, 147-153.

Giardini, M. 2007. Late Quaternary vegetation history at Stracciacappa (Rome, central Italy). Vegetation History and Archaeobotany 16, 301-316.

Giraudi, C. 2004a. The Apennine Glaciations in Italy. In Ehlers,J., Gibbard, P.L. (eds.), Quaternary Glaciations-Extent and Chronology, Part. I: Europe. Elsevier, Amsterdam, pp. 215-223.

Giraudi, C. 2004b. The Upper Pleistocene to Holocene sediments on the Mediterranean island of Lampedusa (Italy). Journal of Quaternary Science 19 (6), 537-545.

Giraudi, C. 2005. Middle to Late Holocene glacial variations, periglacial processes and alluvial sedimentation on the higher Apennine massifs (Italy). Quaternary Research 64, 176-184.

Giraudi, C. 2011. Middle Pleistocene to Holocene glaciations in the Italian Apennines. In J. Ehlers, P.L. Gibbard and P.D. Hughes (eds.), Quaternary Glaciations - Extent and Chronology. A closer look, Developments in Quaternary Science, 15: 211-219, Elsevier.

Giraudi, C. 2012a. The Campo Felice Late Pleistocene Glaciation (Apennines - Central Italy). Journal of Quaternary Science 27 (4), 432-440.

Giraudi, C. 2012b. The Holocene record of environmental changes in the "Stagno di Maccarese" marsh (Tiber River delta - Central Italy). The Holocene 22 (12), 1461-1471.

Giraudi, C., Frezzotti, M. 1997. Late Pleistocene glacial events in the Central Apennine, Italy. Quaternary Research 48 (3), 280-290.

Giraudi, C., Zanchetta, G., Sulpizio, R. 2013. A Late-Pleistocene phase of Saharan dust deposition in the high Apennine mountains (Italy). Alpine and Mediterranean Quaternary 26 (2), 111122.

Giraudi, C., Bodrato, G., Ricci Lucchi, M., Cipriani, N., Villa, I.M., Giaccio, B., Zuppi, G.M. 2011. Middle and Late Pleistocene Glaciations in the Campo Felice basin (Central Apennines Italy). Quaternary Research 75, 219-230.

Hughes, P.D., Woodward, J.C. 2008. Timing of glaciation in the Mediterranean mountains during the last cold stage. Journal of Quaternary Science 23, 575-588.

Hughes, P.D., Woodward, J.C., Gibbard, P.L. 2006. Quaternary Glacial History of the Mediterranean Mountains. Progress in Physical Geography 30, 3: 334-364.

Jaurand, E. 1998. Glaciers disparus de l'Apennin: géomorphologie et paléoenvironments glaciaires de l'Italie peninsulaire. Monographie de l'Université de la Sorbonne, Geographie $10,382 \mathrm{pp}$. 
Lowe, J.J. 1992. Lateglacial and early Holocene lake sediments from the northern Apennines, Italy- pollen stratigraphy and radiocarbon dating. Boreas 21, 193-208.

Magny, M., de Beaulieu, J.L., Drescher-Schneider, R., Vannière, B., Walter-Simonnet, A.V., Millet, L., Bossuet, G., Peyron, O. 2006. Climatic oscillations in central Italy during the Last Glacial-Holocene transition: the record from Lake Accesa. Journal of Quaternary Science 21, 311-320.

Magri, D., Sadori, L. 1999. Late Pleistocene and Holocene pollen stratigraphy at Lago di Vico, central Italy. Vegetation History and Archaeobotany 8, 247-260.

Narcisi, B. 2001. Palaeoenvironmental and palaeoclimatic implications of the Late-Quaternary sediment record of Vico volcanic lake (central Italy). Journal of Quaternary Science 16 (3), 245-255.

Nimmergut, A.P., Allen, J.R.M., Jones, V.J., Huntley, B., Battarbee, R.W. 1999. Submillennial environmental fluctuations during marine Oxygen Isotope Stage 2: a comparison analysis of diatom and pollen evidence from Lago Grande di Monticchio, South Italy. Journal of Quaternary Science 14, 111-123.

Ohmura, A., Kasser, P., Funk, M. 1992. Climate at the equilibrium line of glaciers. Journal of Glaciology 38, 130, 397-411.

Palmentola, G., Acquafredda, P., Fiore, S. 1990. A new correlation of the glacial moraine in the Southern Apennines, Italy. Geomorphology 3, 1-8.

Ramrath, A., Nowaczyk, N.R., Negendank, J.F.W. 1999. Sedimentological evidence for environmental changes since 34,000 years from Lago di Mezzano, central Italy. Journal of Paleolimnology 21, 423-435.

Sadori, L., Jahns, S., Peyron, O. 2011. Mid-Holocene vegetation history of the central Mediterranean. The Holocene 21 (1), 117-129.

Schmidt, R., van den Bogaard, C., Merkt, J., Müller, J. 2002. A new lateglacial chronostratigraphic tephra marker fort he south-eastern Alps: The Neapolitan Yellow Tuff (NYT) in Längsee (Autria) in the context of a regional biostratigraphy and paleoclimate. Quaternary International 88, 45-56.

Siani, G., Sulpizio, R., Paterne, M., Sbrana, A. 2004. Tephrostratigraphy study for the last 18,000 ${ }^{14} \mathrm{C}$ years in a deep-sea sediment sequence for the South Adriatic. Quaternary Science Reviews 23, 2485-2500.

Svensson, A., Andersen, K.K., Bigler, M., Clausen, H.B., Dahl-Jensen, D., Davies, S.M., Johnsen, S.J., Muscheler, R., Rasmussen, S.O., Röthlisberger, R., Steffensen, J.P., Vinther, B.M. 2006. The Greenland ice core chronology 2005, 15-42 ka. Part 2: comparison to other records. Quaternary Science Reviews 25, 3258-3267.

Svensson, A., Andersen, K.K., Bigler, M., Clausen, H.B., Dahl-Jensen, D., Davies, S.M., Johnsen, S.J., Muscheler, R., Parrenin, F., Rasmussen, S.O., Röthlisberger, R., Seierstad, I., Steffensen, J.P., Vinther, B.M. 2008. A 60000 year Greenland stratigraphic ice core chronology. Climate of the Past 4, 47-57.

Watts, W.A., Allen, J.R.M., Huntley, B. 1996. Vegetation history and palaeoclimate of the last glacial period at lago Grande di Monticchio, southern Italy. Quaternary Science Reviews $15,133-153$.

Wulf, S., Kraml, M., Brauer, A., Keller, J., Negendank, J.F.W. 2004. Tephrochronology of the 100 ka lacustrine sediment record of Lago Grande di Monticchio (southern Italy). Quaternary International 122, 7-30.

Zolitschka, B., Negendank, J.F.W. 1996. Sedimentology, dating and palaeoclimatic interpretation of a 0.73 ka record from Lago Grande di Monticchio, southern Italy. Quaternary Science Reviews 15, 101-112. 